\begin{tabular}{l|l|l|l|l}
\hline Volume 2 & Issue 2 & August (2021) & DOI: 10.47540/ijsei.v2i2.256 & Page: $143-154$ \\
\hline
\end{tabular}

\title{
Habitat Ecology of Epiphytic \& Terrestrial Orchids in Langchenphu, Jomotsangkha Wildlife Sanctuary, Bhutan
}

\author{
Kelzang Choden ${ }^{1}$, Jambay $^{2}$, Arjun $\mathrm{Nepal}^{3}$, Choden $^{4}$, Bhagat Suberi ${ }^{5}$ \\ ${ }^{1,4}$ Department of Forest and Park Services, Ministry of Agriculture and Forest, Royal Government of Bhutan \\ ${ }^{2,3,5}$ Department of Forest Science, College of Natural Resources, Royal University of Bhutan
}

Corresponding Author: Arjun Nepal; Email: nepaalarjun1994@gmail.com

\begin{tabular}{|c|c|}
\hline A R T I C & E I N F O \\
\hline Keywords & Bark Texture; Canopy \\
\hline Coverage & Host Condition; Zonation. \\
\hline Received & : 17 May 2021 \\
\hline Revised & : 18 July 2021 \\
\hline Accepted & : 21 July 2021 \\
\hline
\end{tabular}
\begin{abstract}
A B S T R A C T
Orchids are the largest and diverse families of flowering plants. Orchids are found growing mostly in tropical climates affecting various communities socioeconomically. Among many protected areas in Bhutan, Jomotshangkha Wildlife Sanctuary (JWS) is the least explored in terms of flora and fauna. The study was carried out to assess diversity, host tree preferences and to determine the growth zone of epiphytic orchids along the altitudinal gradient in Langchenphu gewog in JWS. Transect technique was used in which three trails transect were laid out with 10 sampling plots in each transect. Plots size of $20 \mathrm{~m} \times 20 \mathrm{~m}$ along the altitudinal gradients were established maintaining an altitudinal interval of 100 meters between each sample plot. A total of 42 species of epiphytic orchids from 20 genera was recorded of 23 host tree species under 15 families were recorded. A significant correlation between diversity of orchid and altitude was observed $(r=.927, p<.05)$. Myrtaceae and Theaceae were the most preferred host tree families (14\%) followed by Bignoniaceae (13\%) and others respectively. The Study concludes that $57 \%$ of total species encountered prefers higher canopy \& on a tree with rough bark, Pearson chi-square test $\left(\mathrm{X}^{2}(1)=4.7, \mathrm{p}<.05\right)$ showed a significant difference between trunk, branches, and canopy. Many epiphytic orchids prefer dense canopy $(\mathrm{n}=73,47 \%)$ and living trees $(99 \%)$. Future studies should be focused more on the flowering season for obtaining better information on orchid diversity in the study area.
\end{abstract}

\section{INTRODUCTION}

Orchids are one of the largest families of flowering plants (Chase et al., 2015; Cribb et al., 2003; Kaiser, 1993) in the plant kingdom with estimates of 25,000 to 35,000 species and $800-1000$ genera distributed throughout the world (Zotz, 2013; Gogoiet al., 2012) of which two-thirds are epiphytes with a main distribution in tropical forest (Gentry and Dodson, 1987). They are mostly annual and perennial herbs and are adapted to diverse climates as epiphytes, lithophytes, terrestrial, and saprophytes (Joshi et al., 2009; De and Medhi, 2015; Yonzone et al., 2012; Zhang et al., 2018).

The epiphyte uses the host tree only for support and provides a habitat for insects and micro-organisms (Vance and Nadkarni, 1990). The family Orchidaceae is considered to have the highest rate of speciation but also the highest rate of extinction (Swartz and Dixon, 2009). Bhutan has 469 orchid species (DoFPS, 2018). Orchids represent more than $10 \%$ of the total flora of Bhutan and 14 species are endemic to Bhutan; of these six are epiphytes and eight are terrestrial (Pearce et al., 2002).

Epiphytic orchids have important ecological values and immensely contribute to forest biodiversity such as increasing species diversity, primary productivity, biomass, litterfall, water retention, and provide a substrate for nitrogenfixing bacteria (Munoz et al., 2003). They also provide essential habitat and food for canopy dwelling fauna and are sensitive indicators of change in microclimate (Gentry and Dodson, 1987).

The epiphytic orchid species are found distributed at a wide range of altitudes depending upon the suitability of the environment on which 
they could thrive (Yonzone et al., 2012). Environmental conditions associated with altitude exert a strong influence on orchid species composition and distribution (Jacquemyn et al., 2005). Species composition along altitudinal gradient can often be related to temperature, the difference in nutrient availability, and plant speciation (Jacquemyn et al., 2005). The changing pattern of rainfall and forest coverage also influence the diversity of orchids (Joshi et al., 2009).

Orchid, one of the largest families of flowering plants that faces an uncertain future through overexploitation, habitat loss due to human activities, and impacts of climate change (Barman and Devadas, 2013; Benzing, 2004; Seaton et al., 2013). Orchids have become vulnerable to extinction because of excessive anthropogenic pressure. Habitat Fragmentation, illegal collection, habitat destruction, increased susceptibility to fire threat, pollinator decline will result in the drastic loss in orchid population and diversity (Coats and Dixon, 2007; Orchids-status survey and conservation action plan, 1996). The decrease in orchid's population is due to deforestation, lopping, construction of farm roads, power transmission lines, illegal collection, and trade (Bajracharya, 2005).

The abundant species of orchids in the sanctuary are facing increasing pressure from developmental activities like the construction of farm roads and power transmission lines which result in huge losses of forests to a clearing. The livelihood income of local people residing in this area is generated from livestock farming. Thus, unsustainable lopping of tree branches as fodder by local people also poses a serious threat to the orchid habitat.

The study aimed to determine the diversity, the most preferred host tree, and the most suitable growth zone of the epiphytic orchids. The study is the first of its kind, which would serve as baseline information and will also provide the sanctuary with relevant information on the checklist of orchids.
This research is expected to generate information baseline information that may be useful for the formulation of guidelines, management activities implementation, and in setting conservation priorities for orchid's biodiversity in protected areas.

\section{MATERIALS AND METHODS Study area}

The study was carried out in Jomotshangkha Wildlife Sanctuary (JWS). The sanctuary is the second smallest protected area ranging from 200 meters above sea level to 2300 masl covering an area of 334.73 sq. km located in south-eastern Bhutan (Department of Forest and Park Service (DoFPS), 2018). Langchenphu gewog experiences hot and humid weather during the summer. Langchenphu gewog gets heavy precipitation from June till the end of September and winter is cool and dry (Dzongkhag administration, Samdrup Jongkhar, 2018). The vegetation in JWSincludes sub-tropical forest, cool broadleaved forest, warm broadleaved forest, and a few grasslands along the southern fringes along the river basins (DoFPS, 2018).

The sanctuary covers the five administrative blocks viz, Phuntshothang, Pemathang, Samrang, Langchenphu, and Serthig: bordered by the Indian state of Assam to the south, NyeraAmachhu to the west, Serthigeog to the north, and Arunachal Pradesh to the east (DoFPS, 2018).

Despite its small acreage (JWS), the area is an important habitat for Asian elephants, Gaur, Bengal Tiger, Chinese Pangolin, Common leopard, Himalayan Black Bear Asiatic golden cat, Marbled cat, Clouded leopard, and Leopard cat. Furthermore, it is known for the habitat of the critically endangered species Pygmy Hog (Procula salvania Hodgson) and Hispid Hare (Caprolagus hispidus Pearson, 1839) (Protected areas of Bhutan, 2016). 


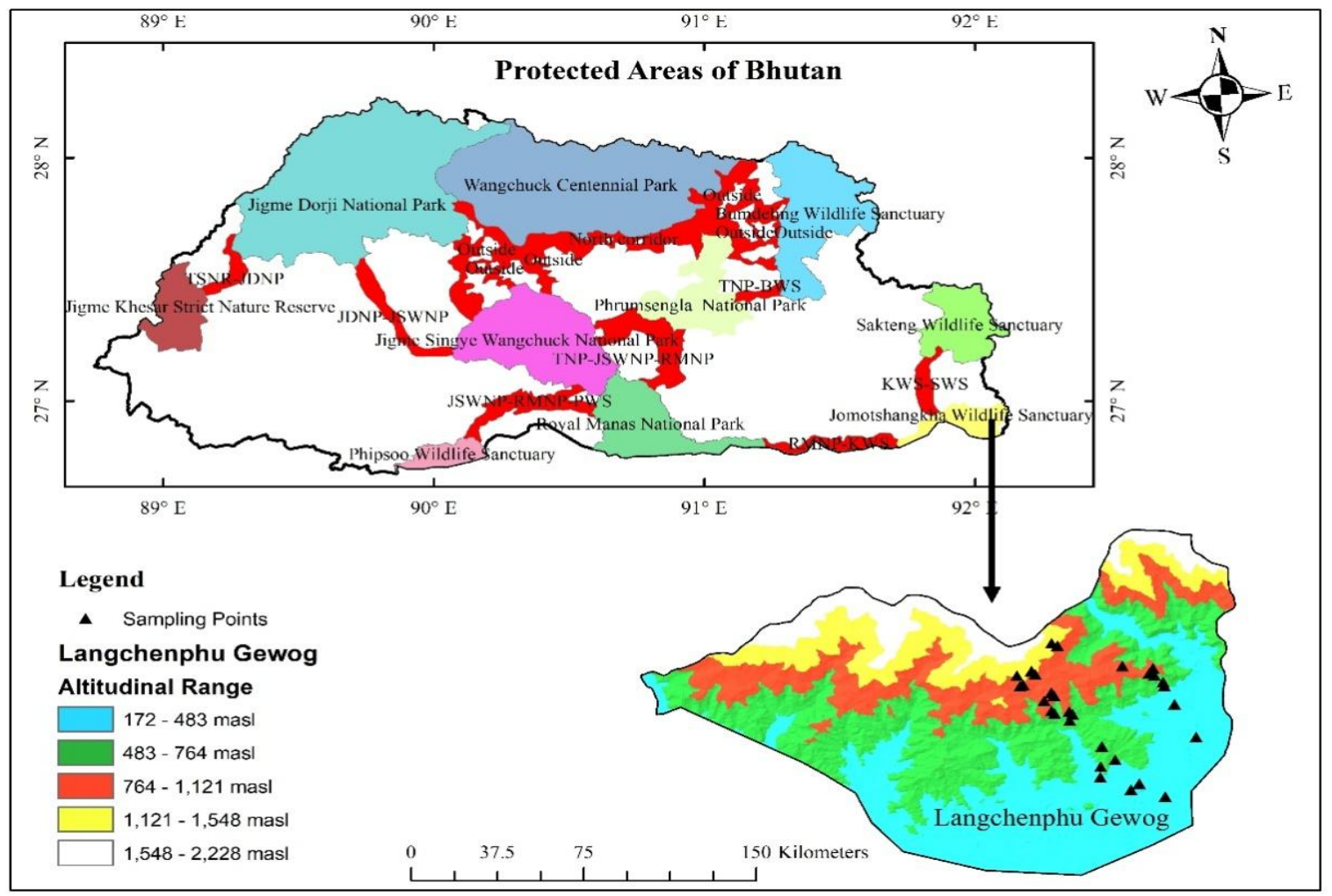

Figure 1. Study area map different elevation range

\section{Sampling design}

The survey methodology for the epiphytic orchid species includes transect techniques and systematic random sampling (Pyakurel \& Gurung, 2014). A total of 3 transects was laid and a square sample plot size of 20 x $20 \mathrm{~m}$ (Nepal \& Dorji, 2020) was established along the altitudinal gradients from 300 masl to 1200 masl maintaining an altitude interval of 100 meters between each sample plot. From each transect, a total of 10 sample plots were laid to collect and record the data. The data on diversity, host preference, and pattern of growth on host trees were recorded from a total of 30 sample plots of size $20 \times 20 \mathrm{~m}$. The division of the three transects was based on altitude since it is one of the important factors influencing orchid distribution.

All the orchid species (terrestrial and epiphytic)occurring within the sampling quadrat (20x20m). Orchids were identified using herbarium specimens in National Biodiversity Centre Serbithang, Thimphu, and Flora of Bhutan (Grierson and Long, 2001; Noltie, 1994) and "Know The Plants Of Bhutan" (Thinley, 2004). The number of individual species for sympodial orchids like Bulbophyllum, Cymbidium, Dendrobium, etc., was counted per clump (Warseno and Arinasa, 2013).

From each sample plot, trees above DBH $\geq 10$ $\mathrm{cm}$ were considered an appropriate host for sampling epiphytes because phorophytes having DBH less than $10 \mathrm{~cm}$ provides smaller surface area and thus hold either very few numbers or no vascular epiphyte species (Hietzand Seifert, 1995).

A tree species with $\mathrm{DBH} \geq 10 \mathrm{~cm}$ seemed safe to climb (i.e. no obvious sign of branch rot) and also contained more epiphytes (Hietzand Seifert, 1995). Ecological factors supporting epiphytic orchid growth (e.g. host tree and growth zones) on host trees were also recorded. The epiphyte's growth position on the host tree was determined by using the zonation method where the host trees were partitioned into three zones: Zone (1) = Basal, from the ground to the diameter at breast height (dbh), Zone (2) = Trunk (from the dbh to the first branch and Zone) (3) = Canopy, (from the first branch to the tip of the tree) (Mojiol et al., 2009). The site factors like latitude, longitude, altitude, aspect, slope, bark texture, and canopy cover were also recorded. 


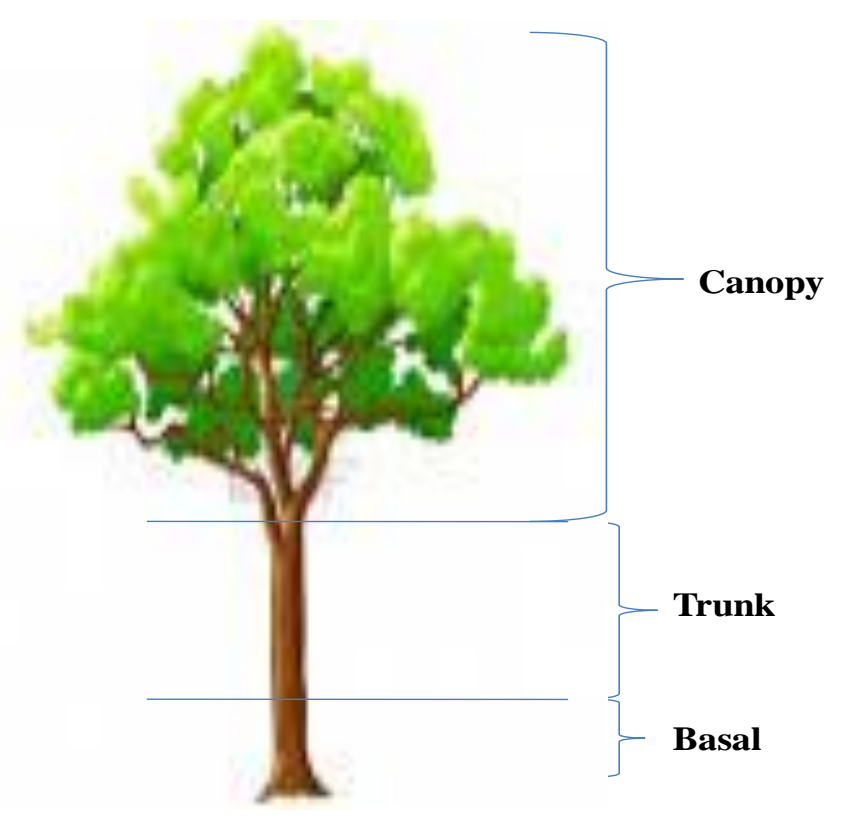

a) Zone 1: Basal, from ground level to the diameter at breast height ( $\mathrm{dbh}$ )

b) Zone 2: Trunk, from dbh to the first branch

c) Zone 3: Canopy, from first branch to the tip of tree

Figure 2. Zonation of epiphytic orchids on the host tree (Adapted from Mojiol et al., 2009).

Canopy coverage was graded into three criteria based on the degree of the canopy cover; dense for the canopy coverage with $>70 \%$ open for the canopy coverage $<70 \%$ and very open for solitary(Wangdi, 2016).

\section{Data Analysis}

The data compilation, sorting, filtering, and cleaning were done in Microsoft Excel. The statistical test was performed using Software R. Spearman correlation was performed to test the association between altitude and epiphytic orchid diversity. A chi-square correlation test was performed to check the correlation between epiphytic orchids preferring trunk and canopy.

\section{Diversity}

Species diversity $\left(H^{\prime}\right)$ was calculated following the Shannon and Weiner diversity index (Shanon, 1948). Species diversity was calculated using Shannon's diversity

$\mathrm{H}^{\prime}=-\sum_{\mathrm{i}=1}^{\mathrm{s}}(\mathrm{pi})$ ( Lnpi) Equation 1

Where, $P$ is the proportion $(\mathrm{n} / \mathrm{N})$ of individuals of one particular species found (n) divide by the total number of individuals found $(\mathrm{N})$. $\mathrm{Ln}$ is the natural $\log$ and $\Sigma$ is the sum of the calculations.

\section{Abundance}

Abundance is defined as the number of species "A" found in all plots to the total number of plots in which the species occurred.

Abundance $=$ Total number of individual species (n) Equation 2 Total number of the plots in which the species occur $(\mathrm{N})$

\section{RESULTS AND DISCUSSION \\ Composition of epiphytic orchids}

A total of 42 species of epiphytic orchids from 20 genera and 8 species of terrestrial orchids from 7 genera were recorded from 30 plots, as shown in (Table 1). Amongst all genera, as shown in Table 1, Flickengeria was found to be relatively high in species abundance with one species $(R A=25 \%, n=$ 108), and Cymbidium, Esmeralda, and Thunia were found relatively low with one species $(R A=1 \%, n=$ 11) respectively. A total of 1022 individuals were recorded from these altitudinal classes.
Among 42 species including incidental record, Aeridesodorata Lour. was encountered which is classified as an endangered species by IUCN. Some other species listed in CITIES Appendix II like Bulbophyllumcareyanum (Hook.) Spreng., Bulbophyllum crassipes Hook.f., Bulbophyllumguttulatum (Hook.f.) N.P. Balakr., Dendrobium transparens Wall.ex Lindl, Esmeralda clarkei Rchb.f., Papilionanthe teres (Roxb.) Schltr, \& Rhynchostylis retuse (L.) Blume was were also found in the study area. Some of the epiphytic orchid's species in the field are shown in Figs 1-6. 


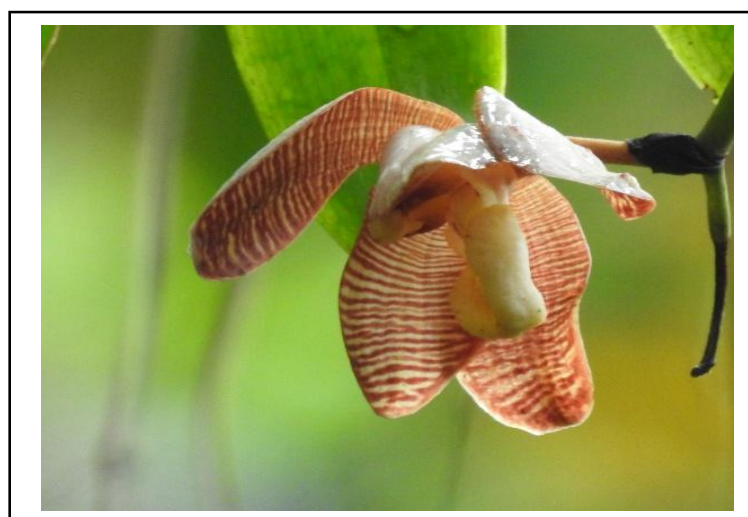

Figure 1. Esmeralda clarkei Rchb.f. Courtesy: Tashi (JWS)

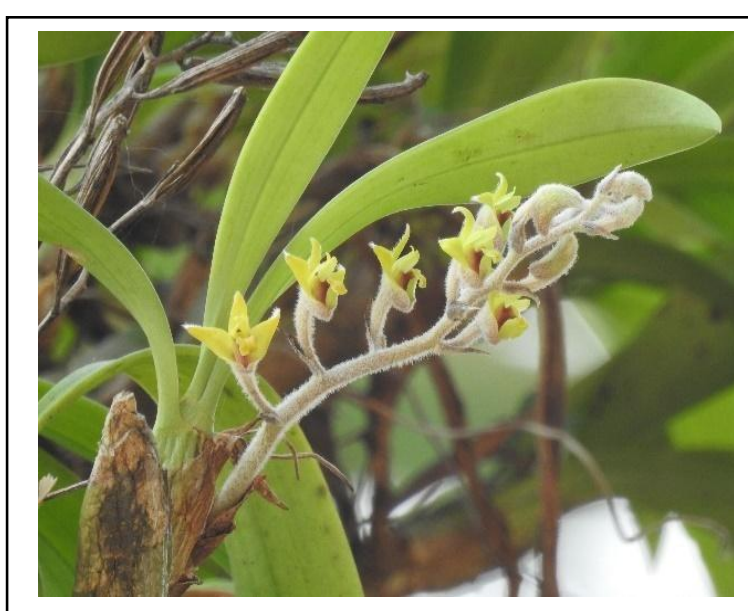

Figure 3. Eria lasiopetala (Willd.)

Courtesy: Tashi (JWS)

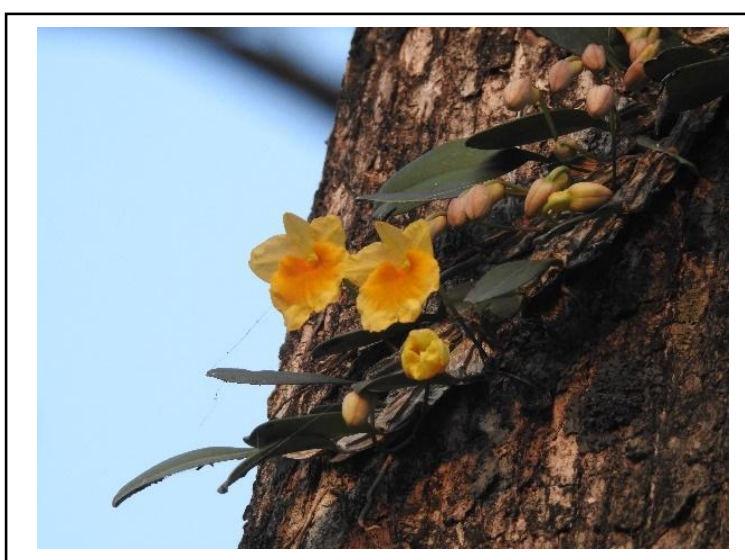

Figure 5. Dendrobium jenkensiii Wall ex.Lindl Photo courtesy: Tashi (JWS)

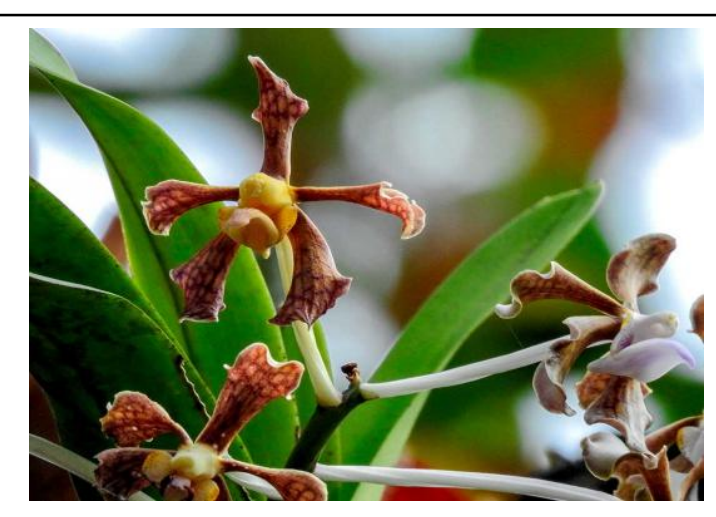

Figure 2. Vanda bicolor Griff.

Courtesy: Tashi (JWS)

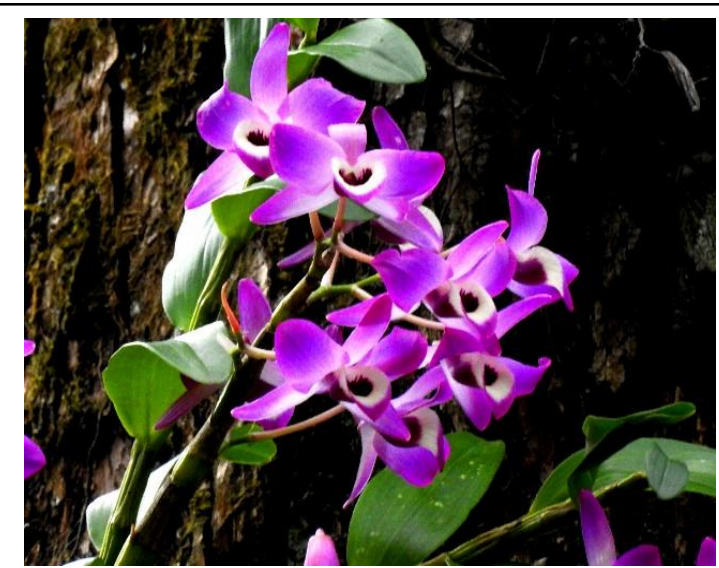

Figure 4. Dendrobium nobile Lindl Courtesy: Tashi (JWS)

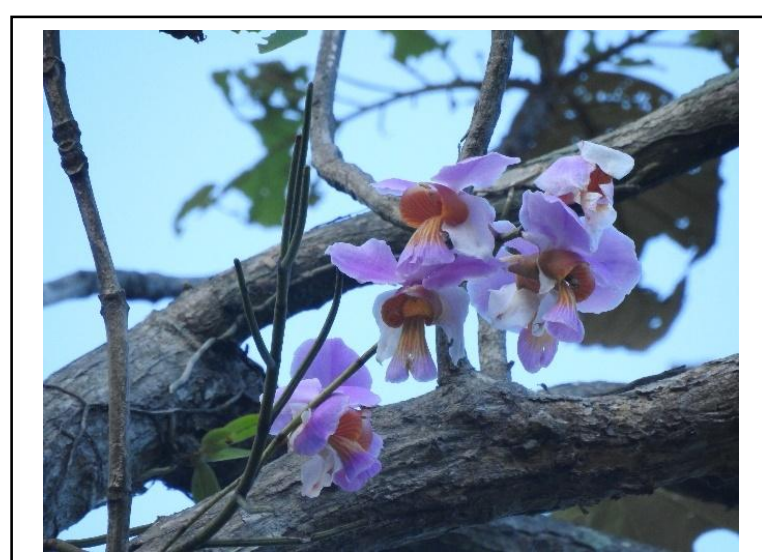

Figure 6. Papilionantheteres (Roxb.) Schltr.

Photo courtesy: Tashi (JWS) 
Table 1. List of epiphytic orchids recorded

\begin{tabular}{|c|c|c|}
\hline Genus & Orchid Species & Altitude (masl) \\
\hline Acampe & Acampe papillosa (Roxb.) Blatt \& McCann & $400-700$ \\
\hline \multirow{2}{*}{ Aerides } & Aerides multiflorum Roxb. & $300-600$ \\
\hline & Aerides odorata Lour. & $300-900$ \\
\hline Ascocentrum & Ascocentrum ampullaceum (Roxb.) Schltr. & 900 \\
\hline \multirow{6}{*}{ Bulbophyllum } & Bulbophyllum affine Wall. ex Lindl. & $900-1100$ \\
\hline & Bulbophyllum careyanum (Hook.) Spreng. & $800-1100$ \\
\hline & Bulbophyllum crassipes Hook.f. & $801-1200$ \\
\hline & Bulbophyllum guttulatum (Hook.f.) N.P. Balakr. & 1100 \\
\hline & Bulbophyllum gymnopus Hook.f. & $700-1100$ \\
\hline & Bulbophyllum leopardinum (Wall.) Lindl. & 1200 \\
\hline Callostylis & Callostylis rigida Blume & $700-800$ \\
\hline \multirow{3}{*}{ Coelogyne } & Coelogyne barbata Lindl.ex Griff. & $1100-1200$ \\
\hline & Coelogyne nitida (Wall.ex D.Don) Lindl & 1200 \\
\hline & Coelogyne prolifera Lindl & $700-1200$ \\
\hline Cymbidium & Cymbidium aloifolium (Linneaus.) Swartz. & $300-700$ \\
\hline \multirow{9}{*}{ Dendrobium } & Dendrobium aphyllum (Roxb.) C.E.C. Fisch. & $500-800$ \\
\hline & Dendrobium chrysanthum Wall.ex Lindl. & 1200 \\
\hline & Dendrobium densiflorum Lindley. & $600-1200$ \\
\hline & Dendrobium fimbriatum Hook. & $300-900$ \\
\hline & Dendrobium gibsonii Paxton & 800 \\
\hline & Dendrobium jenkensiii Wall. Ex Lindl. & $800-1100$ \\
\hline & Dendrobium nobile Lindl & $400-1300$ \\
\hline & Dendrobium spatella Rchb.f. & 1200 \\
\hline & Dendrobium transparens Wall.exLindl & 700 \\
\hline \multirow{2}{*}{ Eria } & Eria coronaria (Lindl.) Rchb.f. & $1000-1100$ \\
\hline & Eria lasiopetala (Willd.) & $300-700$ \\
\hline Esmeralda & Esmeralda clarkei Rchb.f. & 1200 \\
\hline Flickengeria & Flickingeria fugax (Rchb.f.) Seidenf. & $300-600$ \\
\hline Mycaranthes & Mycaranthes pannea (Lindl) S. C. Chen \& J. J. Wood & 900 \\
\hline Oberonia & Oberonia acaulis Griff & $1100-1200$ \\
\hline \multirow{2}{*}{ Otochilus } & Otochilus fuscus Lindl. & $800-1200$ \\
\hline & Otochilus lancilabius Seidenf. & 1200 \\
\hline Papilionanthe & Papilionanthe teres (Roxb.) Schltr. & 800 \\
\hline \multirow{3}{*}{ Pholidota } & Pholidota articulate Lindl. & $600-800$ \\
\hline & Pholidota imbricate Hook. & $300-600$ \\
\hline & Pholidota pallida Lindl. & 900 \\
\hline \multirow{2}{*}{ Pinalia } & Pinalia spicata (D.Don) & $700-1100$ \\
\hline & Pinalia stricta (Lindl.) Kuntze & $900-1200$ \\
\hline Rhynchostylis & Rhynchostylis retuse (L.) Blume & $500-700$ \\
\hline Thunia & Thunia alba (Lindl.) Rchb.f. var. alba & $400-900$ \\
\hline \multirow{2}{*}{ Vanda } & Vanda bicolor Griff. & 1000 \\
\hline & Vanda cristata Wall.exLindl. & $1100-1200$ \\
\hline
\end{tabular}


Table 2. List of terrestrial orchids recorded in the study area

\begin{tabular}{cllc}
\hline SI.No. & Genus & Orchid species & Altitude found (m) \\
\hline 1 & Phaius & $\begin{array}{l}\text { Phaius flavus (Blume) Lindl. } \\
\text { Phaius mishmensis (Lindl \& Paxton) }\end{array}$ & 500 \\
& & Arundina graminifolia (D.Don) Hochr & 1100 \\
2 & Arundina & Goodyera procera (Ker Gawl.) Hook & 300 \\
3 & Goodyera & Crepidium josephianum (Rchb. F.) Marg & 400 \\
4 & Crepidium & Calanthe plantaginea Lindl. & 900 \\
5 & Calanthe & Habenaria furcifera Lindl. & 1200 \\
6 & Habenaria & Acanthephippium striatum Lindl. & 900 \\
7 & Acanthephippium & 1100 \\
\hline
\end{tabular}

Variation in a diversity of orchids along a different altitudinal gradient

Study shows that the diversity peaked at midelevation between $800 \mathrm{~m}$ to $1100 \mathrm{~m}$, with diversity declining both at higher and lower elevations (Figure 7). Altitude is one of the factors that strongly influence the distribution of epiphytic orchids (Adhikari et al., 2012). The diversity of epiphytic orchids at lower altitudes was found to be less because the area was mostly covered with settlements and there was less vegetation coverage. At the higher elevations because of more moisture and lower livestock grazing, the percentage of the vegetation cover was significantly higher (Qanbari \& Jamali, 2015). The high diversity of orchids in mid-altitude is defined by mid domain hypothesis. The hypothesis is applicable in the current study (Shacha et al., 2021) which states overlapping of species richness in mid-altitude and decreasing at the edge.

The diversity patterns of vascular epiphytes along an elevational gradient in the Andes peaks at mid-elevation at $1500 \mathrm{~m}$ (Kromer et al., 2005), and in this study diversity is highest in the elevational zone between 800 and 1200 masl, where $=2.01, H^{\prime}$ $=2.49$ respectively. The results also concur with the findings of Warseno and Arinasa (2013) who reported that the diversity of orchid species are more at 500-1500 masl.

Precipitation and moisture plays important role in the distribution of orchids. Due to heavy precipitation at the mid-elevation of JWS, a high number of orchids were recorded from this zone. Jalal (2012) stated that the altitude between 1000 2000 masl has much higher rainfall than other higher altitudinal zone, which makes this zone a more suitable habitat for orchid growth and development.
To study its association Spearman's correlation test was performed which showed that there is a strong significant relationship between the altitude and epiphytic orchid diversity $(r=.927, p$ $<.05$ ). The high temperature and low rainfall of the low altitudinal zone $(<500 \mathrm{~m})$ have suppressed orchid growth due to insufficient humidity and soil moisture(Jalal, 2012).

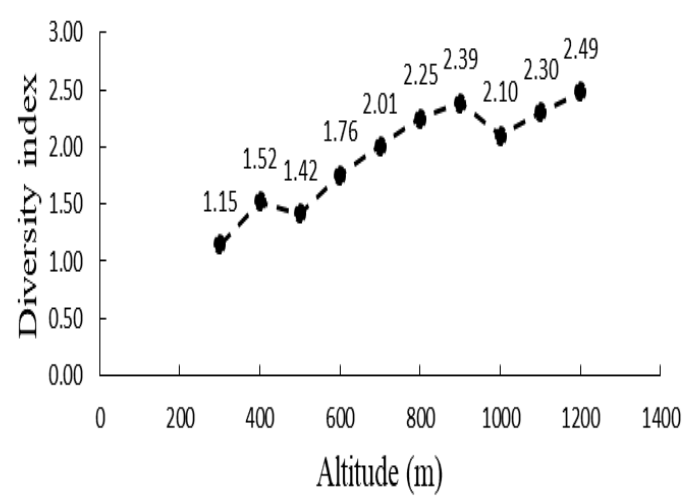

Figure 7. Diversity of epiphytic orchids at different altitude

\section{Composition of host tree species}

Hirata et al. (2008) specify that to sustain and survive in a favorable environment, the host tree providing a good substrate is important for epiphytic orchids. A substrate is a surface on which an organism like a plant, fungus, or orchid can live. Some orchids are restricted to a specific host. A total of 156 host trees $(M=6.78 \pm 6.80)$ representing 23 species under 15 families and 21 genera were recorded in three transects. Amongst the host tree species Schima wallichii (DC.) Korthand Syzygium cumini $(n=22)$ was found to be most abundant, followed by Stereospermumchelonoides (L.fil.) Dc. $(n=21)$, and least by Aphanamixis polystachya (Wall), Bauhinia purpureaL, Calicarpaarborea Roxb, 
Phobelanceolate (Nees) Nees. and Rubus niveus Thunb $(n=1)$ each as shown in Table 2.

Table 3. List of 23 host species

\begin{tabular}{llc}
\hline Family & Host Tree Species & \% Coverage \\
\hline Myrtaceae & Syzygiumcumini L. & 14 \\
Theaceae & Schima wallichii (DC.) Korth & 14 \\
Bignoniaceae & Stereospermumchelonoides (L.fil.) Dc & 13 \\
Fagaceae & Castanopsi hystrix Miq & 8 \\
Altingiaceae & Altingia excelsa (Noronha) & 7 \\
Magnoliaceae & Magnolia hodgsonii (Hook.f \& Thomson) H. Keng & 5 \\
Lamiaceae & Tectona grandis L. F & 5 \\
Malvaceae & Pterospermumacerifolium (L.) Willd & 4 \\
Lauraceae & Beilschmiedia sikkimensis & 4 \\
Combretaceae & Terminalia bellirica (Gaerth) Roxb. & 3 \\
Bignoniaceae & Stereospermumcolais (Buch-Ham. Ex Dillw). D.L. Mabberley & 3 \\
Magnoliacaae & Magnolia pterocarpa Roxb. & 3 \\
Lauraceae & Litsea hookeri (Meisner) D.G Long & 3 \\
Lythraceae & Duabanga grandiflora (Roxb. ex. DC) & 3 \\
Malvaceae & Sterculia villosa Roxb. & 2 \\
Lauraceae & Cinnamomum glanduliferum (Wall.) Meisn & 2 \\
Rosaceae & Rubus niveus Thunb. & 1 \\
Lauraceae & Phobe lanceolate & 1 \\
Fabaceae & Leucaena leucocephala (Lam.) de Wit & 1 \\
Moraceae & Ficus racemose L & 1 \\
Lamiaceae & Calicarpa arborea Roxb. & 1 \\
Fabaceae & Bauhinia purpurea L & 1 \\
Meliaceae & Aphanamixis polystachya (Wall) & 1 \\
Total & &
\end{tabular}

The host trees under the same families were grouped to see the most preferred host tree species by epiphytic orchid species. Lauraceae was the largest host tree family with four species constituting $21 \%$ of the total species encountered in the study area. The species were $B$. sikkimensis, $C$. glanduliferum, L. hookeri and P. lanceolata. The data showed the least preferred families as host trees were Altingiaceae, Combretaceae, Fagaceae, Lythraceae, Meliaceae, Moraceae, Myrtaceae, Rosaceae, and Theaceae constituting 4\% of total species encountered in the study area.

\section{Canopy Coverage}

Distributional patterns of epiphytic orchids on the stems and branches of the host tree are influenced by the need for sunlight and humidity that make epiphytic orchids favor specific zones (Yulia and Yanti, 2010). Canopy coverage plays important role in the availability of sunlight for optimal growth of orchids (Harwati, 2007). It was found that epiphytic orchids prefer a dense canopy to the open ones in JWS. The frequency of orchids preferring dense canopy was relatively high. Species preferring dense canopy was $47 \%(n=73)$ of all individuals in the study area, open canopy with $37 \%(n=58)$ and very open with $16 \%$ of $(n=$ $25)$ as shown in figure 8 . 


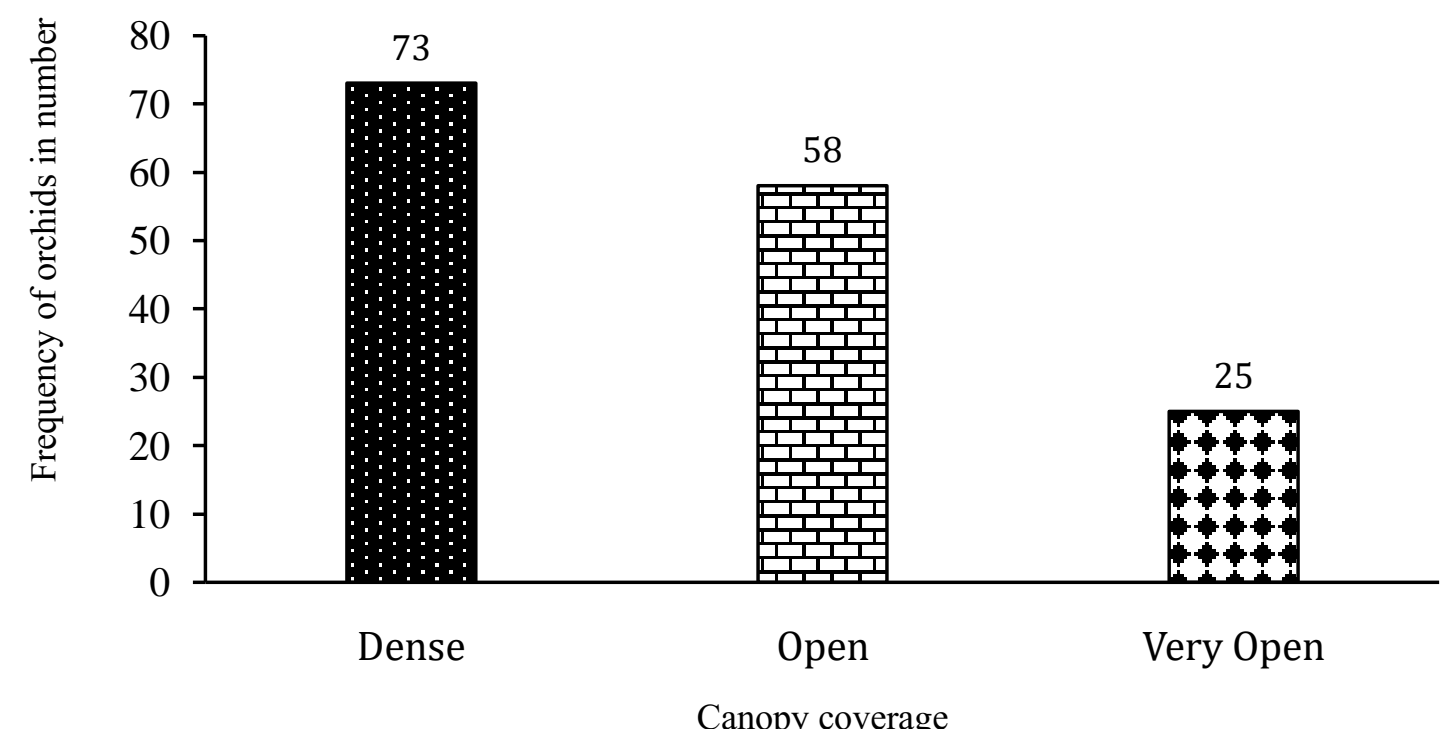

Figure 8. Canopy Coverage and the frequency of orchids

In this study, a greater number of orchids were found growing on a host tree with a dense canopy similar observation was made by Dobbs (2006), that trees with most canopy coverage have maximum epiphyte orchids coverage since they prefer moist and shady environments but lower epiphytes cover was found at the bottom of the tree because of the moisture trapping ferns and other plants on the ground.

Petruzzelo (2019), has found most of the epiphytes in moist tropical areas where their ability Growth Zone of Epiphytic Orchids to grow above the ground level provides access to sunlight available from leaf and other organic debris that collects high in the tree canopy.

Since the study area falls under subtropical forest (Banerjee and Bandopadhyay, 2016) it receives high rainfall (Corlett and Hughes, 2015) and the canopy layer retains more moisture because of the presence of leaves. So, the epiphytic orchids prefer to grow on the canopy layer in JWS as there is more moisture contained and high humidity which helps in their optimal growth.

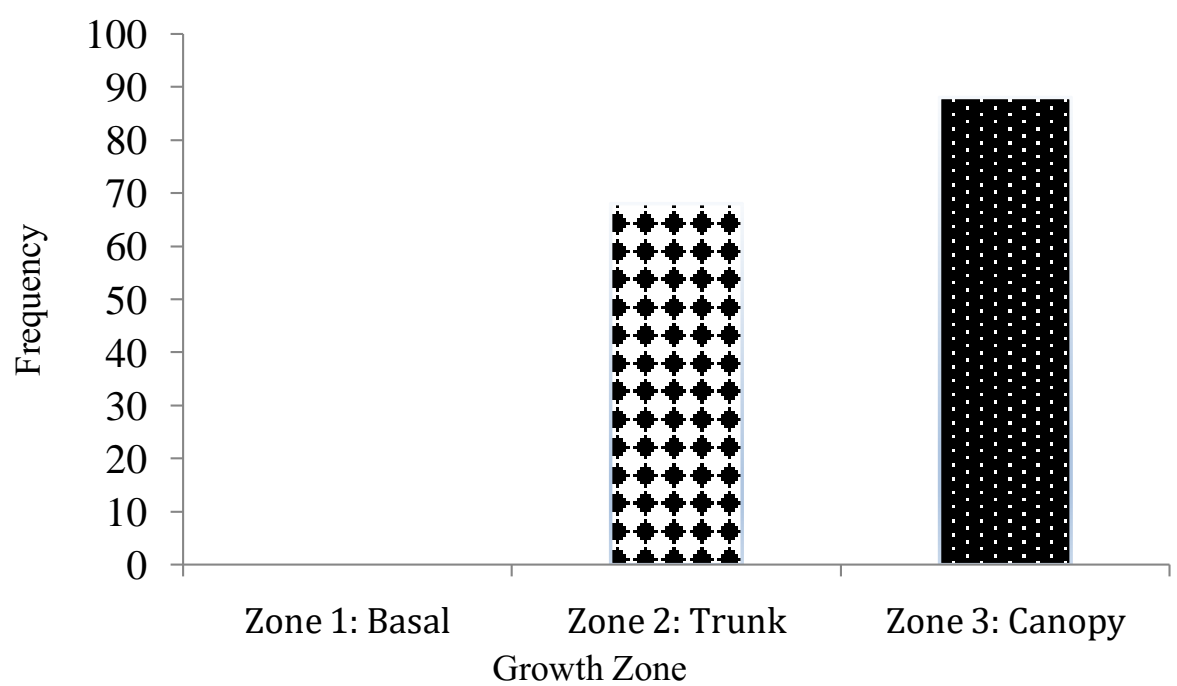

Figure 9. Growth/height zone preferred by epiphytic orchids

Maximum epiphytic orchids prefer canopy with $56 \%$ of all individuals encountered (Growth Zone 3), followed by Trunk (Zone 2) with $44 \%$ of all individuals encountered and there were no epiphytic orchids found towards the basal portion of the tree (Zone 1). To validate further Chi-square correlation test was performed which showed a significant correlation with epiphytic orchids 
preferring trunk and canopy $\left(\mathrm{X}^{2}(1)=14.76, p<\right.$ .05). As per Mojiol et al. (2009), the zonation method of epiphytic orchids reveals that species is abundant in the canopy zone than at the base and trunk of the host tree. Furthermore, (Sillet,1999; Doverspike, 2017), reported that the presence of branches in the canopy layer may result in an accumulation of dust, which encourages epiphytes to grow. Since many species prefer canopy, it's important to have proper canopy management in an operated forest.

\section{CONCLUSION}

Epiphytic orchid diversity at JWS is relatively high, there were 42 epiphytic orchid species and 8 terrestrial's orchids though the study was done in a small area of Langchenphu gewog.

A total of $156(\mathrm{~N})$ individual host trees were recorded representing 23 species under 15 families and 21 genera. This data reveals that Langchenphu harbors many more species which were not encountered during the study. The study concludes that orchids are found most at an elevation of 4501200 masl. A most important factor affecting its distribution was precipitation, humidity, and temperature. Canopy coverage plays important role in its growth, so it's important to have proper guidelines in forest management guidelines addressing this issue too.

Since orchids can be a source of income for rural livelihood through ecotourism in the sanctuary in the future, locals need to be made aware of their importance. Habitat fragmentation has been a hot issue for the last decades in biodiversity conservation. Detail study on endangered orchids is highly recommended for conservation purposes.

\section{REFERENCES}

Adhikari, Y. P., Fischer, H. S., and Fischer, A. J. (2012). Host tree utilization by epiphytic orchids in different land-use intensities in Kathmandu Valley, Nepal. Plant Ecology, 213(9), 1393-1412.

Bajracharya, Devendra and Shrestha, K.K.. (2003). Eria nepalensis (Orchidaceae), a new species from Nepal. 78. 158-161.

Banerjee, A., and Bandopadhyay, R. (2016). Biodiversity hotspot of Bhutan and its sustainability. Current Science, 110, 523.
Benzing, D. H. (2004). Vascular epiphytes. In: Forest canopies, 175-211.

Bulafu, C. C., Kakudidi, E. K., and Mucunguzi, P. (2007). Diversity of terrestrial orchids of Mt. Elgon Forest National Park, Eastern Uganda. African Journal of Ecology, 45(2), 21-28.

Cribb, P. J., Kell, S. P., Dixon, K. W., \& Barrett, R. L. (2003). Orchid conservation: a global perspective. Orchid conservation, 124.

Coats, D. J., and Dixon, K. W. (2007). Current perspective in plant conservation. Australian Journal of Botany,55, 187-93.

Corlett, R.T., and Hughes, A.C. (2015). Subtropical Forest. The Routledge Handbook of Forest Ecology. Routledge, Oxford, UK. pp. 46-55

Dawa, K. (2015). Population status, host preferences and growth zone of epiphytic orchids on the host trees in the Royal Botanical Park along a different altitudinal gradient (Unpublished B. Sc thesis). College of Natural Resources, Royal University of Bhutan.

De, L. C., and Medhi, R. P. (2015). Orchid- A diversified component of farming systems for profitability and livelihood security of small and marginal farmers. Journal of Global Biosciences, 4, 1393-1406.

Department of Forest and Park Services. (2018). Jomotshangkha Wildlife Sanctuary. Thimphu, Bhutan: Ministry of Agriculture and Forest.

Didham, R.K., Tylianakis, J.M., Hutchison, M.A., Ewers, R.M., and Gemmell, N.J. (2005). Are invasive species the drivers of ecological change? Trends in ecology and evolution, 20(9), 470-474.

Dobbs, A. M. (2006). Factors influencing epiphyte habitat preferences in Moorea, French Polynesia. California, USA: Department of Plant and Microbial Biology, University of California.

DoFPS. (2018). Forest Facts and Figures. Retrieved from:

http://www.dofps.gov.bt/?page_id=116

(Accessed on: 5 August 2020).

Doverspike, L. (2017). Symbiotic relationship between an orchid and a tree. www.gardenguides.com. (Accessed 21 April 2019) 
Dressler, R. L. (1981). The orchids. Natural History and classification. Cambridge: Harvard University Press.

Dressler, R. L. (1993). Phylogeny and classification of orchid family. Cambridge: Cambridge University Press.

Gentry, A. H., \& Dodson, C. (1987). Contribution of non trees to species richness of a tropical rain forest. Biotropica, 149-156.

Ghimire, M. (2014). Epiphytic orchids of Nepal. Banko Janakari, 18(2), 53.

Gogoi, K., Borah, R. L., Sharma, G. C., and Yonzore, R. (2012). Present Status of Orchid Species Diversity Resources and Distribution in Dibrugarh District of Assam of North East India. International Journal of Modern Botany, 2(2), 19-34.

Grierson, A. J., and Long, D. G. (2001). Flora of Bhutan, including a record of plants from Sikkim. (Vol. 2): Royal Botanic Garden.

Gurung, D. B. (2006). An illustrated guide to the orchids of Bhutan. Thimphu, Bhutan: DSB Publications.

Handa, S. S. (1986). Orchids for drugs and chemicals. In: biology, conservation and culture of orchids, 89-100.

Hietz, P., and Seifert, H. U. (1995). Composition and ecology of vascular along an altitudinal gradient in central Veracruz, Mexico. Journal of Vegetation Science,6(4), 487-498.

Jalal, J. S. (2012). Distribution pattern of orchids in Uttarakhand, Western Himalayas, India. International Journal of Plant Biology, 3(5), 24-26.

Joshi, G. C., Tewari, L. M., Lohani, N., Upreti, K., Jalal, J. S., \& Tiwari, G. (2009). Diversity of orchids in Uttarakhand and their conservation strategy with special reference to their medical importance. Report and opinion, 1(3), 47-52.

Kromer, T., Kessler, M., Gradstein, S. R., and Acebey, A. (2005). Diversity patterns of vascular epiphytes along an elevational gradient in Andes. Journal of Biogeography, 32, 1799-1809.

Migenis, L. E., \& Ackerman, J. D. (1993). Orchidphorophyte relationships in a forest watershed in Puerto Rico. Journal of Tropical Ecology, 9.
Mojiol, A. R., Jitinu, A. A., Adella, A., Ganang, G. M., and Nasley, N. (2009). Vascular epiphytes diversity at Pusatsejadi, Kawang Forest Reserve. Journal of Ecology, 2(1), 121-127.

Nepal, A., \& Dorji, U. (2020). Composition and Diversity Pattern of Climbers in Tropical Forest of Langchenphu, Jomotshangkha Wildlife Sanctuary. Bhutan Journal of Natural Resources \& Development, 7(1): 4050.

Noltie, H. J. (1994). Flora of Bhutan, including a record of plants from Sikkim. (Vol. 1): Royal Botanic Garden.

Orchids-status survey and conservation action plan. (1996). Retrieved from Gland, Switzerland and Cambridge, UK:

Pearce, N. R., Grierson, A. J., Cribb, P., Long, D. G., \& Bates, M. (2002). Flora of Bhutan; including a record of plants from Sikkim and Darjeeling. Royal Botanical Garden Edinburgh.

Petruzzelo, M. (2019). Epiphyte plant type. http://www.britannica.com/plant/epiphyte. (Accessed 26 April 2019)

Phelps, J., and Webb, EL. (2015). Invisible wildlife trades: South Asia's undocumented illegal trade in wild ornamental plants. Biological conservation. 186: 296-305.

Protected areas of Bhutan. (2016). http://www.dofps.gov.bt/. (Accessed 26 April 2019)

Pyakurel, D., and Gurung, K. (2014). Resource Assessment method for epiphytic orchids.In proceeding of National Workshop on NTFP/MAPS Sector Action Plan Development. 56-59.

Kaiser, R. A. (1993). On the scent of orchids.

Qanbari, V., \& Jamali, A. A. (2015). The relationship between elevation, soil properties and vegetation cover in the ShorbOI-Ain watershed of Yazd. Journal of Biodiversity and environmental sciences, 6(5), 49-56.

RSPN. (2016). Protected areas of Bhutan. http//:www.rspnbhutan.com. Accessed on 14 April 2019.

Seaton, P., Kendon, J. P., Pritchard, H. W., Puspitaningtyas, D. M., \& Marks, T. R. (2013). Orchid Conservation; the next ten 
years. Lantesteriana International Journal on Orchidology, 13(1-2), 93-101.

Shacha, N., Dorji, Y., Nepal, A., Choden, S., Ghally, T. B., \& Dendup, K. C. (2021). Regeneration Status and Soil Nutrient Content in Burned Blue Pine Forest in Thimphu, Western Bhutan. Indonesian Journal of Social and Environmental Issues (IJSEI), 2(1), 48-58.

Shannon, C. and Wiener, W. (1963). The mathematical theory of communications. Urbana: University of Illinois Press.

Sillet, S. C. (1999). Tree crown structures and vascular epiphytes distribution in Sequoia sempervirens rainforest canopies. Selbyana, 20 (1), 76-79.

Solinkin, Suhartono, and Tarmudji. (2010). Composition and dispersal of orchid species in Lejja South Sulawesi; proceeding of national seminary of basic science. Malang: Brawijara University.

Swarts, N. D., and Dixon, K. W. (2009). Terrestrial orchid conservation in the age of extinction.Annals of Botany, 104, 543-556.

Vance, E. D., and Nadkarni, N. M. (1990). Microbial biomass and activity in canopy organic matter and the forest floor of a tropical cloud forest. Soil Biol Biochem, 22,677-684.

Wangdi, J. (2016). Study on host tree preferences and growth zone of epiphytic (orchidaceous) Cymbidium species in Sakteng gewog under Sakteng Wildlife Sanctuary. (Unpublished B. Sc thesis, College of Natural Resources, Royal University of Bhutan.

Warseno, T., and Arinasa, I. K. (2013). Epiphytic orchid and Host Tree Inventory in Bulus Pattanunang Protected Forest- Marus South Sulawesi. Maros South Sulawesi: UPT Botanical Gardens Plant Conservation Center.

Yonzone, R., Lama, D., Bhujel, R.B., \& Rai, S. (2012). Orchid species diversity of Darjeeling Himalaya of India. International Journal of Pharmacy and life sciences, 3(3).

Zotz, G. (2013). The systematic distribution of vascular epiphytes - a critical update. Botanical Jornal of the Linnean Society, 171(3), 453-481.
Zhang, S., Yang, Y.-J., Li, J.-W., Qin, J., Zhang , W., Huang, W., \& Hu, H. (2018). Physiological diversity of orchids. Plant Diversity, 40(4), 196-208. 